\title{
The Structure and Development of the Haustorium of Striga lutea.'
}

\author{
BY \\ EDITH L. STEPHENS, B.A., F.L.S.
}

With Plate XCII.

TRIGA LUTE A, Lour. ' (the Witchweed or Rooibloem-'Red Flower') $\mathcal{N}$ is a semi-parasitic annual belonging to the Order Scrophulariaceae. It occurs in scattered localities throughout Zululand, Natal, and the Transvaal, on various native grasses and also on $Z e a$ Mays, which is an important South African food-crop. Its life-history is now being studied by Professor Pearson, to whom I am indebted for the supply of material and for much helpful information as to its life-history and mode of growth. Most of the material investigated was collected by him on the maize crops in the Transvaal; the remainder was obtained from cultures of Striga on the maize reared in this laboratory.

\section{The Plant.}

Striga lutea is a root parasite which passes a portion of its life-history underground in the form of a slender white shoot bearing scales, leaves, and numerous adventitious roots. Later, the shoot grows above ground into a slender green-branched stem, 2 to 18 inches high, bearing decussating pairs of linear leaves and spikes of bright red flowers. ${ }^{3}$ The adventitious roots arising from the underground portion of the shoot branch freely and come into contact with the root-system of the maize plant on which the seedling parasite has established itself. The roots of host and parasite form a network in which those of the Striga plant are readily distinguished by the absence of root-hairs, by their transparency and paler colour (the endodermis of the maize showing through the cortex and giving the root a yellowish tinge), and often also by the presence of small patches of a reddish secretion (giving reactions for mucilage) on their surface. At points where roots of the two come in contact or approach one another

1 This investigation was assisted by a grant from the Union Government.

- Fide Flora Capensis, vol. iv, sect. 3, p. 445.

3 See figure of plant, Burtt Davy ('04), Plate LXXIV A.

[Annals of Botany, Vol. XXVI. No. CIV. October, 1012.]

4 A 2 
closely, haustoria grow out from the Striga root and penetrate that of the maize. In Fig. I is shown (in optical section) a root of Striga which has run parallel to a maize root for a short distance, and has developed a row of haustoria penetrating the maize. Fuller figures ${ }^{1}$ part of a shoot of Striga showing the connexion between its underground root-system and that of the maize, but his figure makes the Striga shoot apparently end in a tap-root, an error which is corrected in Burtt Davy's copy ${ }^{2}$ of Fuller's plate. Fuller also gives ${ }^{3}$ several diagrammatic sketches of sections of the haustoria, but no details of their structure or development have yet been published. It is the object of the present investigation to supply these details.

\section{THE HAUSTORIUM.}

\section{(a) General Structure.}

Compared with the haustoria of other phanerogamic parasites, that of Striga is comparatively simple in structure. Typically, it is almost globular in outline (Pl. XCIII, Fig. I), and consists mainly of a mass of transparent nucleated cells which, following the usage of other writers, I will refer to as the 'nucleus' 4 (n., Figs. I, 5, 6). This is surrounded by a cortex of varying thicknesses (c., Figs. I, 5, 6). Down the centre of the 'nucleus' runs a strand of tracheides, linking the vascular system of the parasite to that of the host (a.s.t., Figs. I, 5, 6). This strand can be most clearly seen in Fig. 5, which shows an optical longitudinal section of a young haustorium which has penetrated into a maize root as far as the endodermis. This haustorium still retains the lenticular shape characteristic of its earlier stages, being at the most only six cells deep back to front. Its transparency thus enables its structure to be studied in optical section, though the outlines of the cells of the 'nucleus' at the median focus of the figure are obscured by those lying above, so that only a few were seen with sufficient clearness to be drawn in. They can be better seen in Fig. 6, which shows an older haustorium (which has attained its full size and globular outline) cut in a plane transverse to both mother root and haustorium. This section is slightly oblique to the axis of the haustorium, so that the connexion of the axial strand of tracheides with the vessels of the mother root is not seen.

\section{(b) Origin and Early Development.}

The chief interest attaching to these haustoria lies in the fact that the very delicate and transparent nature of the parent root and young haustorium enables the origin and development of the latter to be studied

1 Fuller ('01), Pl. V. 'Burtt Davy ('04), Pl. LXXIV A. 'Fuller, loc. cit.

- Barber ('06), Benson ('10). Fraysse ('06) refers to this tissue as ' noyau méristématique central' or 'masse méristématique centrale'. Other writers give it no special name. 
quite clearly in optical section up to the stage of Fig. 5. This is of interest as throwing light on the much-debated point as to whether the haustoria of root-parasites in general are to be regarded as much-modified lateral roots, or as special exogenous outgrowths. In the case of Striga the haustoria show no homologies with lateral roots, being markedly exogenous in their origin, which is from the cells of the subhypodermal or (more rarely) the hypodermal layer. It cannot of course be said with certainty that every haustorium has originated from one of these layers, but even in the older stages it is clear that it has taken its rise in one of the layers between epidermis and endodermis. The haustoria may arise on roots of any agee. g. the young haustoria of Figs. 3 and 4 are growing from roots decidedly older than in the case of the more mature haustorium of Fig. 5. As to the cause of their originating at any particular point, it may perhaps be of significance that the early stages of development have only been seen on roots which were in close proximity to young roots of maize still covered with root-hairs, and that the length of the haustorium before it penetrates the host (e. g. such a haustorium as that of Fig. 5) is about that of a maize root-hair. These facts lead me to put forward the purely tentative suggestion that stimulus due to contact with a hair of the maize root may be the determining cause of their development.

Superficially, the haustorium first appears as a slight elevation on the surface of the root, elongated parallel to its axis. In a side view (in optical section) this elevation is seen to be due to the elongation of several (3-5) cells of the subhypodermal or hypodermal layer (Fig. 2). These cells are situated in the same row, parallel to the axis of the root, and the developing haustorium is therefore elongated in that direction. They begin to divide by transverse and longitudinal walls, pushing up the overlying layer or layers still further to form a protuberance which is cone-like in section (Fig. 4) but elliptical in surface view. Thus the young haustorium of Fig. 3 is only 3-4 cells deep back to front (i. e. above the level of the mother-root), and that of the later stage shown in Fig. 4 is only 4 cells deep. This later stage is formed from that of Fig. 3 (if this has not by now come in contact with a maize root) by its growing out still further into a blunt finger-like process (Fig. 4); which may be twice as long as the root from which it develops is broad. It never seems to develop further than this without contact with the root of the host. Only one case of selfattachment was seen; in this the haustorium was still of the size and general shape of Fig. 4, and had penetrated to the depth of about three cells into the cortex of the Striga root, with which its cells then gradually merged. None of the developments which are seen when the haustorium touches a foreign root had taken place.

The cells of the developing haustorium have the appearance of ordinary cortical cells, and it never assumes the small-celled and meristematic 


\section{ro70 Stephens. - The Structure and Development of the}

appearance characteristic of the developing root, which has here an ordinary endogenous development. Numbers of young lateral roots and haustoria have been seen arising side by side on the mother root, and it is clear that there is no resemblance between them in origin, development, or structure.

\section{(c) Connexion with Host.}

Penetration of the soft cortical tissues of the maize root is rapidly effected when once the haustorium comes into contact with it. Stages in which the tip of the haustorium has not already penetrated to the endodermis are rarely found. When the epidermal cells of the haustorium touch the host root they begin to elongate, forming papillae of a finger-like form and arranged in palisade rows, which bore their way between and through the cortical cells of the host. Their passage is effected by a ferment they secrete, which swells and ultimately dissolves the cell-walls which it touches. The margin of the advancing haustorium is marked by an irregular clear brigit yellow or yellow-brown line, presumably this ferment plus the dissolved tissues of the host, and the same yellow line is often seen round individual papillae which have grown beyond the level of the rest of the haustorium. This line is represented (marked $f$.) in Figs. 5-8. It stains with safranin, but not with haematoxylin; microchemical tests to determine its nature have yielded no results. The walls of the cells of the host to a distance of several cells from the haustorium may become swollen with the action of the ferment, when they also take on this yellow colour and stain in a similar way (cf. the walls of the endodermal and cortical cells bordering the line of ferment in Fig. 7). The pressure due to growth assists in the passage of the haustorium through the tissues of the host, but to a much less degree, as is shown by the fact that very little collapsed tissue is seen in the path of its advance. Growth pressure is in evidence when individual papillae have to penetrate a hard-walled vessel, as in Fig. 7, where a papilla has evidently had considerable difficulty in penetrating into the central vessel of the maize stele. The wall of the latter has been pushed in, and the length of time that the papilla has taken to effect an entrance can be seen by the spiral thickening formed nearly down to its tip.

A series of longitudinal sections through a haustorium soon after penetration (or an optical section such as Fig. 5) shows that the central papillae have reached the endodermis, and have flattened their ends against it to form several regular palisade layers. With regard to Fig. 5, it must be remembered that it is a median optical section; focusing slightly above or below the level of the section, the papillae in front of and behind the layer figured as abutting on the endodermis can be seen as it were crawling over its surface trying to effect an entrance. As soon as the ferment touches the endodermis, the contents of the cells of the latter disappear, and their outer walls swell (Fig. 7). In Fig. 8 is seen an endodermal cell in longitu- 
dinal section, with several papillae touching its outer wall. This has become so swollen and dissolved by the ferment they have secreted that only its inner line is distinguishable; and the inner wall has also begun to swell. The walls of the endodermal cells in the maize are thicker than those of the cortical cells, the inner considerably so, and the haustorium may enlarge to almost its mature dimensions while the papillae are trying to penetrate them.

Meanwhile, the strand of elongated cells forming the axis of the young haustorium has become converted into the line of tracheides seen in Fig. 5, running from the vessels of the parasite down through the centre of the haustorium to the stele of the host. Sometimes this line of tracheides begins to form almost immediately after the haustorium has begun to penetrate the tissues of the host; sometimes it is only laid down after some amount of cell-division has taken place in the haustorium. The latter seems to be the case when parasite and host lie close together, so that a comparatively short haustorium is formed; the former when the haustorium has had to grow out to some length, and thus is further from the water supply of its mother root. In any case, this line of tracheides is formed in the same way, and apparently always before the haustorium has penetrated through the endodermis, which it takes some time to do. Spiral markings appear in the cells of the two or three layers which lie between the vessels of the mother root and the base of the line of elongated cells forming the axis of the haustorium. The spirals run in the same direction as those of the vessels, and the tracheides thus formed make a little hump on the vascular strand, which links it with these axial cells. (These connecting tracheides can be seen at the junction of the vascular system of the mother root with the axial strand of tracheides in Fig. 5. The two lines of tracheides which appear in the figure to end blindly in the nucellus close to the vascular strand are seen at a slightly higher focus to link on to it by similar connecting tracheides.) In the lowest of these axial cells, i.e. the one contiguous with the connecting tracheides, spiral thickening now appears, and each successive cell in the same longitudinal row becomes converted into a spirally thickened tracheide. Later on, other tracheides are added to this strand by the appearance of spiral markings in the papillae that are striving to pierce the endodermis of the host, and in the cells running up behind them (cf. Fig. 8). A few tracheides have been added in this way to the axial strand of Fig. 5. Comparing it with that of Fig. 6, it will be seen that as these additional tracheides follow the line of the maize stele, the central strand is lenticular in shape, although the haustorium when mature is almost globular. Occasionally in the case of a large haustorium a branch of the axial strand may be formed later on in the 'nucleus' (cf. the left-hand haustorium in Fig. 1).

While this axial strand has been forming, active division has been 


\section{Stephens.-The Structure and Development of the}

taking place in the cells surrounding it. These divide up to form a mass of small transparent nucleated cells-the 'nucleus'. It is interesting to note that this appears to be formed entirely by the renewed division of cells derived from the original subhypodermal layer of the mother root. The two outer layers of the haustorium (derived from the two outermost layers of the root) merely divide to form a cortex several layers in thickness (c., Figs. I, 5, 6; in Fig. 5 the cortex is still only two layers thick in the lower portion of the haustorium). In the younger stages, as Fig. 5, this cortex is still clearly marked off from the small meristematic cells of the 'nucleus', but later on the outer cells of the latter enlarge, lose their slightly rounded outlines, and pass over into ordinary cortical cells (cf. Fig. 6). Around the axial strand, however, they seem to remain active until the death of the haustorium, and perhaps play some part in the transmission of elaborated food-stuffs from host to parasite.

By the time the 'nucleus' is well formed, a line or group of papillae (those which were the first to penetrate the host root) have bored their way through or between the endodermal cells, and are now tapping the vessels of the stele. They penetrate to various depths; in Figs. 6 and 7 one is just entering the large central vessel. Their ends flatten against the vessels as they did against the endodermal cells, and the ferment they secrete dissolves the wall of the vessel. Sometimes the papilla then grows on and penetrates through the opposite wall into the next vessel (cf. Fig. 7), sometimes instead its tip becomes dissolved together with the wall, so that it forms a side pipe tapping the vessel. One vessel may be tapped in this way by a longitudinal row of papillae. Spiral thickenings run up the papillae to their tips, and the tracheides thus formed constitute an efficient conducting system between the xylem of the host and that of the parasite. The further development of the haustorium is the result of the continued division of the cells of the 'nucleus', which causes the haustorium to grow down on either side of the host root till it may come to resemble an indiarubber ball with a stick (the maize root) pressing it in along one side. Several cases have been seen in which the lips of the haustorium had closed round the maize root and destroyed its cortex till its stele appeared to be almost embedded in the haustorium.

Examination of a large range of material has shown that the course of development outlined above is followed in practically every case. The very few exceptions that have been seen will be discussed later in connexion with the comparison of the Striga haustorium with that of other plants. The development of haustoria on the underground shoot may be mentioned here ; this is occasionally seen when a maize root comes in contact with the shoot. No early stages of development of these haustoria have been found, but sections through several mature haustoria have shown them to be of the usual type, except that they are almost embedded in the 
cortex of the stem, and that the tracheides, lacking the definite point of development afforded by the vascular system of the root, run in scattered lines through the 'nucleus' instead of in a central strand. The 'nucleus' seems to grow backwards through the stem, and the lines of tracheides run back with it till they meet and link on to the vessels of a leaf-trace. If they do not meet a leaf-trace, they simply end blindly in the 'nucleus'.

\section{(d) Mechanism of Nutrition.}

The whole question of the nutrition of this parasite, especially during the underground portion of its life-history, is obscure. While the watercarrying vessels of host and parasite are connected so as to allow of a free passage of water and salts, there is no such conducting system for assimilated food. No sieve-tubes are formed in the haustorium, none have been found in the mother roots, and there is apparently no connexion with the phloem of the host. It is of course possible that the parasite may absorb food by osmosis from the sieve-tubes of the host where its thin-walled cells come in contact with these, as is suggested by Peirce ${ }^{1}$ for Arceuthobium occidentale. But as the haustoria fasten only upon the younger roots of the maize, in which the sieve-tubes are not easily distinguished or have not yet been formed, I have not been able to ascertain whether the conditions for such a transference are found here. Until the subaerial shoot is formed, the plant thus apparently has to depend for its supply of assimilated food on the reserve stores passed over from the phloem to the xylem of the host, and on what the haustoria may absorb from the cells dissolved by its ferment. Many microchemical tests have been made to find out what food-stuffs are transferred from host to parasite, but without result. There is no storage, even temporary, of food such as has been recorded for the haustoria of other parasites ${ }^{2}-a$ fact which may be connected with the relatively short life of the haustorium in this case. It is not known just how long an individual haustorium may live, but the fact that they are never seen on the older roots of the full-grown maize shows that their life is not a long one.

\section{DisCUSSION.}

The fact that the haustorium of Striga may be regarded as comparatively simple in structure has already been noted. No glands are formed to assist in penetration $;^{3}$ there are no arrangements of strengthening tissue ; and no 'collapsed layers' are seen, such as are generally found in haustoria which have to penetrate the woody cylinder of dicotyledonous roots. All these facts may be correlated with the comparative ease with which the haustorium

1 Peirce ('05), p. 109. 2 e. g. Barber ('06), Fraysse ('06), Benson ('10), \&c.

- As formed in, e. g., Sartalum album (Barber, '06).

- As seen in, e. g., Osyris alba (Fraysse, '06) and Krameria canescens (Cannon, '10). 
can make its way through the cortex of the maize, and, once the endodermis is passed, into the comparatively slightly lignified vessels of the young root. Here it is interesting to note that several haustoria were found trying to penetrate an unknown dicotyledonous root which possessed a layer of cork about six cells thick round the stele. The haustoria had entered the root as far as the cork, and were striving to penetrate it with the secretion of much ferment, but they had not got half-way through. Though they had grown to the size of the haustorium of Fig. 6, the axial strand of tracheides had not yet been formed, confirming the opinion stated above that this is only formed after the haustorium has penetrated to the stele of the host. ${ }^{1}$ In this case, a line of 'crushed tissue' had been formed down the centre of the 'nucleus'.

The chief interest of this investigation lies in the exactitude with which the origin and development of the haustoria can be followed up through the transparent tissues of the mother root, and in the light which is thus thrown on the disputed question of whether haustoria are to be regarded as organs suigeneris or as much modified lateral roots, a point on which investigators have differed even in regard to the same species. ${ }^{2}$ My first-hand knowledge of the literature of parasitism is not sufficient to enable me to add to the many discussions ${ }^{8}$ on this point, beyond recording the fact that in Striga all the lateral haustoria are clearly exogenous in origin, and show no homologies with the lateral roots. Very rarely a case is found in which the tip of a Striga root has apparently met a maize root and formed a terminal haustorium. I use the word 'apparently' because in every such case but two a new growing point had been formed near the apex of the haustorium (as is described for like cases in Santalum, ${ }^{4}$ Exocarpus, ${ }^{5}$ and Krameria ${ }^{6}$ ). When this new root had grown on, the haustorium would present the appearance of an ordinary lateral one ; but it seemed clear in the half-dozen cases seen that the haustorium was originally terminal. It might of course still have had an exogenous origin from one of the layers of the very simple root-tip, but the appearance of the haustorium would suggest that the cells of the root-tip simply grew out as papillae into the host, the vessels extended down to form the central strand of the haustorium, and the inner cortical cells divided up to form the 'nucleus'. Unfortunately, no young stages in the development of such a haustorium have been seen. It may be noted that these haustoria were all formed at the ends of fairly long roots; it might have been expected that in the case of two roots running parallel, as in Fig. I, penetration by the lateral roots of the haustorium might occur, but no such case was found.

1 Fraysse ('06) remarks of the haustoria of Osyris alba (p. 28): 'Dans aucnn cas, l'appareil vasculaire n'apparait complètement formé avant l'installation définitive do parasite. Dès que la pénétration est suffisante, les trachées se différencient et s'insinuent jusqu'anx divers vaisseaux ... '

Fraysse ('06), p. 23.

4 Barler (06).

Peirce ('93 and '05), Goebel ('05), Fraysse ('06), \&cc.

- Benson ('10).

- Cannon (10). 
The fact that the haustoria here are clearly exogenous, and apparently organs suigeneris, does not of course necessarily mean that in other parasitic plants they are never formed by the modification of root primordia, but it leads one to wish for more exact and detailed descriptions of their origin and development than are generally given, before coming to a conclusion on the point as regards any one plant.

\section{SUMMARY.}

I. Striga lutea is a semi-parasitic South African annual which grows as a root-parasite on native grasses and on the maize. It consists of a slender shoot, the underground portion of which bears many adventitious roots on which haustoria arise.

2. These haustoria are markedly exogenous in origin, being formed by the division of cells of the subhypodermal or hypodermal layer of the root, which push up the overlaying layers to form a finger-like protuberance.

3. When this meets the root of a maize plant, its epidermal cells grow out as papillae and bore their way into the host, by secreting a ferment which dissolves its tissues.

4. Down the centre of the haustorium a line of tracheides is now formed, linking the vessels of root and parasite, and by division of the cells surrounding this axial strand a 'nucleus' of parenchymatous cells is formed, which gives the haustorium a globular outline.

5. The mode of nutrition of the parasite is obscure. There is free passage of water and salts from the host, but although the parasite passes. a portion of its life-history underground as a total parasite, no system is formed for the conduction of assimilated food.

6. The haustoria of this plant are exogenous in development, and are probably to be regarded as organs sui generis.

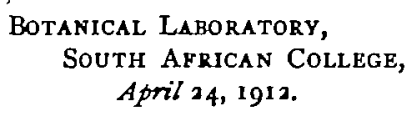

\section{LITERATURE CITED.}

1. Barber, C. A.: The Haustorium of Santalum albws. Mem. Dep. Ag. Ind., Bot. Ser., vol. i, 1906.

2. Benson, Margaret : Root Parasitism in Exacarpus. Ann. Bot., vol. xiiv, 1910, pp. 667-77, P1. LV.

3. Cannon, W. A.: The Root Habits and Parasitism of Krameria carescens, Gray, in D. T. Macdougal and W. A. Cannon, On the Conditions of Parasitism in Plants. Camegie Institution of Washington, Pablication No. $129,1910$.

4. Davy, J. B.: Witchweed or Rooibloemetje. Trans. Agric. Journ., April, 1904. 


\section{Io76 Stephens.-Development of the Haustorium of Striga lutea.}

5. Fraysse, A. : Contribution à la biologie des plantes phantrogames parasites. Montpellier : Société Anonyme de l'Imprimerie Générale da Midi, Série A, No. $5^{1} 5,1906$.

6. Fuller, C. : First Report of the Government Entomologist, Natal, 1899-1900, pp. 20-2 2, Pl. V.

7. Goebel, K. The Organography of Plants. (English Translation.) Oxford, 1900.

8. Peirce, Gronge J.: The Dissemination and Germination of Arceuthobium accidentale, Eng. Ann. Bot., vol. xix, 1905, pp. 99-1 I3, Pl. III and IV.

\section{EXPLANATION OF PLATE XCIII.}

Illustrating Miss Stephens's paper on the Hanstorium of Siriga lutea.

c. $=$ cortex; $n .=$ 'nucleus'; a.s.t. a axial strand of tracheides; $f$. = line of ferment secreted by the haustorium, with the disorganized tissues of the bost dissolved in it.

Fig. I. Optical median longitudinal section of root of $S$. Iutea running alongside root of maize. Four baustoria have penetrated the maire root. $\times 23$.

Fig. 2. Optical median longitudinal section of cortex of a root of $S$. lutea, shoring three cells of the hypodermal layer elongating; these will give rise to a hangtorium. $\times 140$.

Fig. 3. Optical median longitudinal section of portion of root of $S$. luted, showing a young hanstorium originating from cells of the subhypodermal layer. $\times 140$.

Fig. 4. Optical median longitudinal section of root of $S$. lutea, showing a later stage in the development of the haustoriom. $\times 140$.

Fig. 5. Optical median longitudinal gection of haustorinm of $S$. lutea which has penetrated as far as the endodermis of a root of maize. Only such of the cells of cortex and nacleus are drawn in, as conld be seen with distinctness at the focus of the section. $\times 140$.

Fig. 6. Transverse section of a haustorium of $S$. lutea which has penetrated into the stele of a root of the maize. $\times 280$.

Fig. 7. Portion of Fig. 6 enlarged, shoring penetration of papillac of haustorium into vessels of the maize stele. $\times 760$.

Fig. 8. Longitudinal section of a single cell of the endodermis of the maize, showing papillae of the hanstorium secreting ferment which has swollen and dissolved the inner wall of the cell till only its inner limit is perceptible. The outer wall bas also begun to swell, $\times 1100$. 


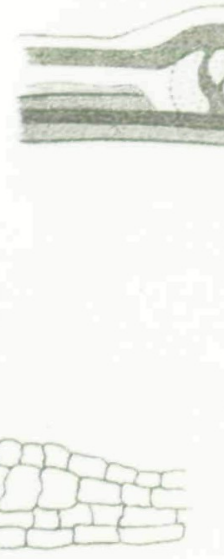

2.
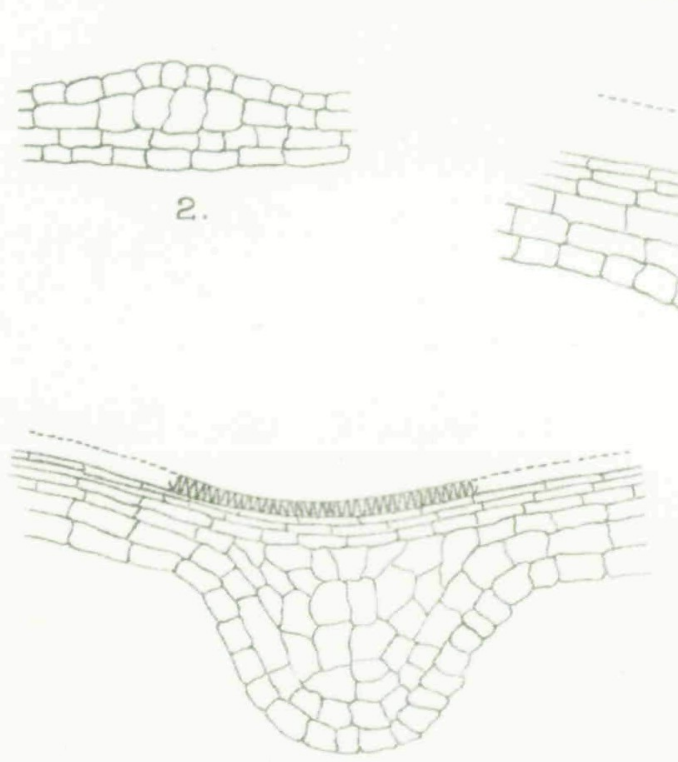

3.

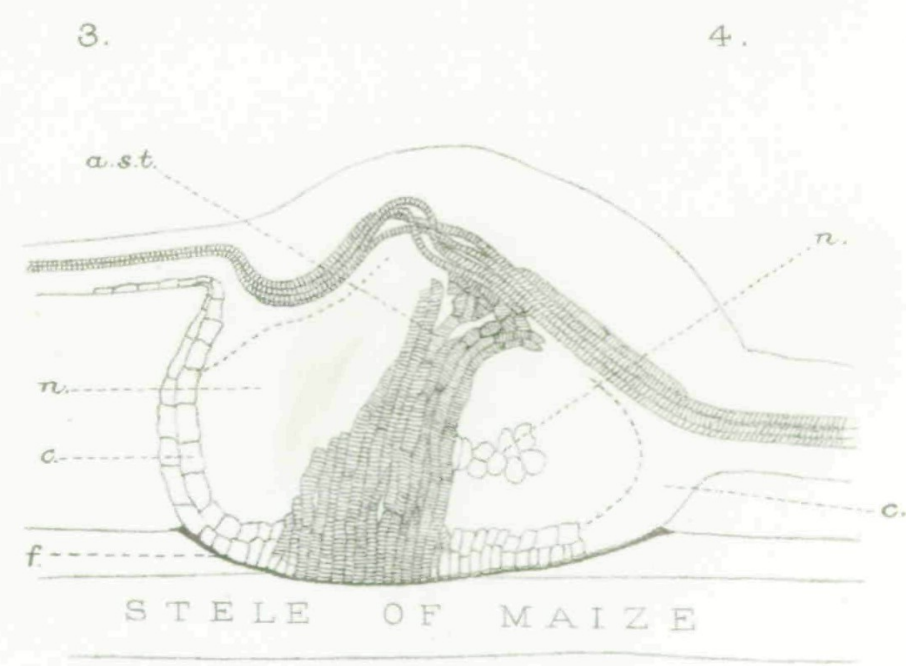

5.
STEPHENS - STRIGA

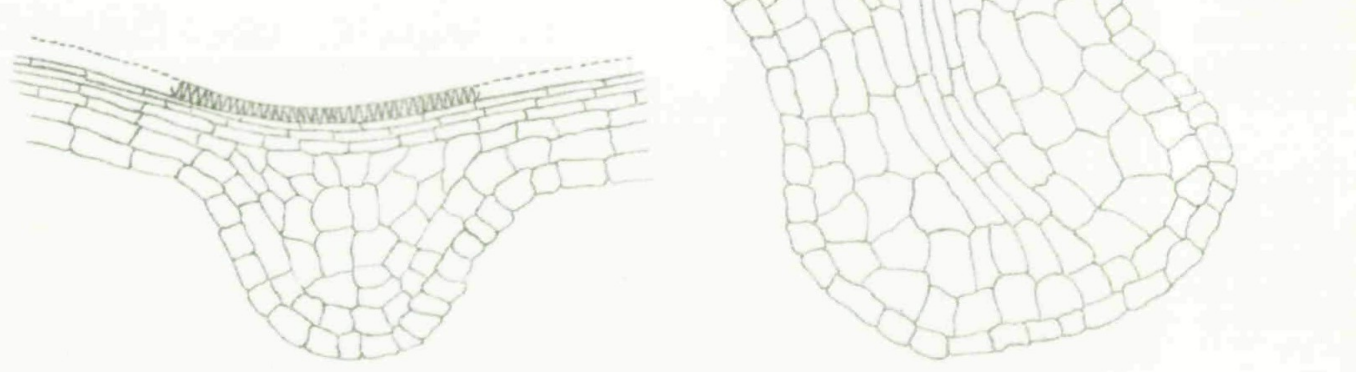

\section{(1)

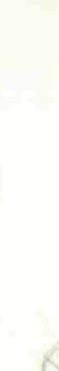

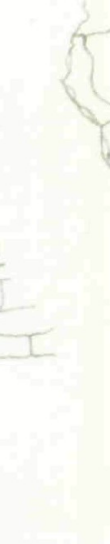

西

(1)

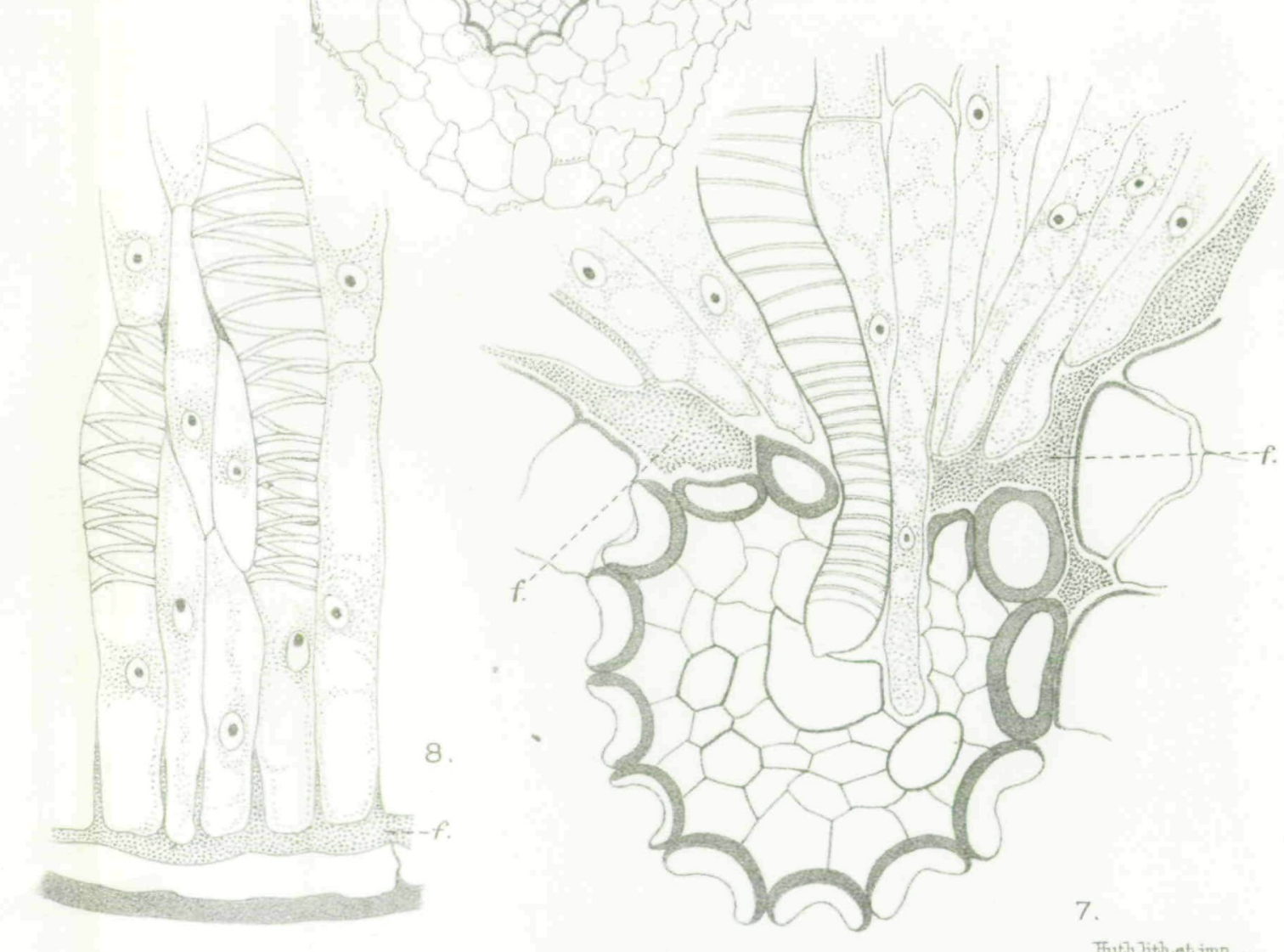

Huth, ith.et imp 


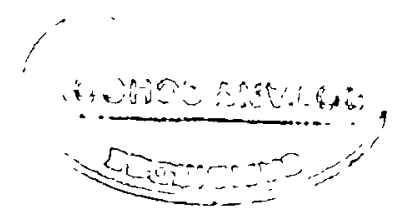

$\frac{1}{2}+\cdots$ 